\title{
DROUGHT AND EXTREME TEMPERATURE TOLERANCE FOR TILLANDSIA DASYLIRIIFOLIA, AN EPIPHYTIC BROMELIAD FROM THE NORTHERN COASTAL DUNE SCRUBLAND IN YUCATAN, MEXICO
}

\author{
Raiza J. Castillo ${ }^{1,3}$, J. Carlos Cervera ${ }^{2}$ and Jorge Navarro-Alberto ${ }^{2}$ \\ 1 University of Florida -Tropical Research \& Education Center. Florida. \\ ${ }^{2}$ Universidad Autónoma de Yucatán, Facultad de Medicina Veterinaria y Zootecnia. \\ Campus de Ciencias Biológicas y Agropecuarias. Departamento de Ecología Tropical. Mérida, Yucatán, México. \\ ${ }^{3}$ Corresponding author: raizajcastilloar@ufl.edu.
}

\begin{abstract}
The ecophysiological investigations about epiphytic plants have focused on the establishment of mechanistic explanations of how plants respond to changes in their environment. The main objective of this work was to assess the drought and extreme temperature tolerance of Tillandsia dasyliriifolia individuals growing in two coastal dune scrub sites with different precipitation patterns and microhabitat distribution. This study was focused on the effect of plant size on tolerance parameters. Drought and extreme temperature tolerance were evaluated in small $(\mathrm{S} 1,9 \mathrm{~cm})$ and large individuals $(\mathrm{S} 2,35 \mathrm{~cm})$. Tolerance between sites was not different but varied between size classes. Tillandsia dasyliriifolia shows moderate tolerance to drought in comparison to more succulent plants. The $50 \%$ of the leaves in small plants died after 40 days of drought and after 60 days for large plants. $T$. dasyliriifolia also exhibits moderate tolerance to extreme temperatures tolerance, small plants tolerate a temperature range from $11^{\circ} \mathrm{C}$ to $40{ }^{\circ} \mathrm{C}$ and the range for large plants is a little broader $\left(9{ }^{\circ} \mathrm{C}\right.$ to $\left.43{ }^{\circ} \mathrm{C}\right)$.
\end{abstract}

Key words: Epiphyte, crassulacean acid metabolism, plant size, drought tolerance, temperature tolerance.

Resumen: Las investigaciones ecofisiológicas sobre las plantas epífitas se centran en establecer mecanismos que expliquen cómo las plantas responden a los cambios en su entorno. El objetivo de este trabajo fue evaluar la tolerancia a la sequía y temperaturas extremas de individuos de Tillandsia dasyliriifolia provenientes de dos localidades de matorral de duna costera con diferentes patrones de precipitación, fisonomía y en la distribución de microhábitats. En ambos sitios se evaluó la tolerancia a la sequía y a temperaturas extremas de individuos de diferentes tamaños, $9 \mathrm{~cm}(\mathrm{~S} 1)$ y $35 \mathrm{~cm}(\mathrm{~S} 2)$. No se encontraron diferencias en las tolerancias entre sitios pero sí entre tamaños $T$. dasyliriifolia es moderadamente tolerante a la sequía, cuando se le compara con plantas más suculentas, ya que el $50 \%$ de las hojas en individuos pequeños murieron hasta los 40 días de sequía y en los individuos grandes hasta los 60 días. La tolerancia a temperaturas extremas de $T$. dasyliriifolia también es moderada. Las plantas pequeñas toleran intervalos entre $11^{\circ} \mathrm{C}$ a $40{ }^{\circ} \mathrm{C}$ mientras que las plantas más grandes de $9{ }^{\circ} \mathrm{C}$ a $43{ }^{\circ} \mathrm{C}$.

Palabras clave: Epifita, metabolismo ácido de las crasuláceas, tamaño de las plantas, tolerancia a la sequía, tolerancia a temperatura.

$\mathbf{M}$ ost ecophysiological studies in epiphytes have focused on getting explanations about plant geographical distribution and how they respond to changes in their habitat (Schmidt et al., 2001). Three of the most important ecological factors influencing plant development and distribution are water, irradiance and temperature (Adams et al., 1997; Lambers et al., 2008; Smith et al., 1997; Zotz 2005).

Water is the most limiting factor for growth and survival in arid environments (Nobel, 1988). Similarly to terrestrial plants in arid environments, epiphytes grow in habitats with dry microclimate, mainly due by intermittent water supply (Benzing, 1978). Epiphytes show modifications to offset drought. For example, many bromeliads present an elaborate phyllotaxis and cavities that hold water, phytotelmata, that in combination create efficient water-storage tanks (Benzing, 1980). Crassulacean acid metabolism (CAM) is a physiological adaptation which confers three to six times higher water use efficiency because stomatal opening occurs at night, when evaporative demand is lower (Nobel, 1988; Ehleringer and Monson, 1993; Winter and Smith, 1996). The atmospheric epiphyte Tillandsia ionantha Planch. after 6 months of drought was still green and maintained a constant level of osmotic and water potential and a positive carbon dioxide uptake (Ohrui et al., 2007). 
Temperature is the factor which best explains the distribution of a species (Gibson and Nobel, 1986; Sanford, 1969). Temperature regulates most of the basic aspects of cell metabolism; high temperatures denature enzymes and lower temperatures freeze tissues and damage cell membranes (Palta et al., 1993; Pastenes and Horton, 1996). Furthermore, most plants grow best when temperatures fluctuate at least a 6 to $7{ }^{\circ} \mathrm{C}$ between day and night (Lüttge, 2004). This is marked in CAM plants because the $\mathrm{CO}_{2}$-binding enzymes, phosphoenolpyruvate carboxylase (PEPC) is stabilized at low temperatures, and Ribulosa 1-5 biphosphate carboxylase (Rubisco) activity is favored by warm temperatures (Carter et al., 1995; Israel and Nobel, 1995). Cold temperature is the major limiting factor that affects the distribution of tropical epiphytes (Benzing, 2000). However, for the atmospheric Tillandsia usneoides (L.) L. low temperature is not limiting (Garth, 1964). Similarly, for Polypodium vulgare L., an epiphytic fern, long severe expositions to frost don't lead to visible damage (Zotz, 2005). Studies of tolerance to high temperatures in epiphytes are lacking. One of the few studies shows that the epiphytic lichen Evernia prunastri (L.) Ach. can tolerate air temperatures of $40{ }^{\circ} \mathrm{C}$ for short periods and exhibits low acclimation to increasing temperatures (Pisani et al., 2007).

Some studies have explored the importance of size-related physiological responses in epiphytes. Almost all studies related to bromeliad size have focused on the measurement of the responses of the photosynthetic apparatus, gas exchange, transpiration rates and morphological changes in relation to environmental factors (Adams and Martin, 1986a, b; Schmidt et al., 2001; Schmidt and Zotz, 2001; Zotz, 1997; Zotz and Thomas, 1999). For example, adult tank-forming bromeliads under well-watered conditions show higher rates of $\mathrm{CO}_{2}$ exchange and transpiration than smaller ones (Adams and Martin, 1986a). Many bromeliads with a rosette growth pattern have the ability to form a tank and store water to avoid drought. However, many tank-forming bromeliads do not have water storage capacity during early stages that could suggest a higher mortality for desiccation than adult plants (Benzing, 2000).

This study compares drought and extreme temperature tolerance for two Tillandsia dasyliriifolia Baker populations and the effect of plant size in these parameters. Tillandsia dasyliriifolia is a CAM bromeliad (Ricalde et al., 2010) that grows along costal dune scrubland vegetation in the northern Yucatan Peninsula. We measured the tolerance of $T$. dasyliriifolia to drought and extreme temperature under controlled conditions. For this experiment, individuals of different sizes and from different populations were tested. Since there is a temperature gradient that decreases to east, while the percentage of winter precipitation increases in the same direction, it is expected that the larger plants from more arid and warmer conditions will be more tolerant to drought and extreme temperature.

\section{Materials and methods}

Study site. The climate of the northern coast of the Yucatan Peninsula is semi-arid and presents a precipitation gradient increasing from west to east (Orellana et al., 2009) San Benito has average mean air temperature of $26^{\circ} \mathrm{C}$, a maximal of $45^{\circ} \mathrm{C}$ and a minimum of $10{ }^{\circ} \mathrm{C}$ and receives less than $500 \mathrm{~mm}$ average annual rainfall, with a dry season from March to May (Orellana, 1999). Ria Lagartos presents an average mean air temperature of $25.6^{\circ} \mathrm{C}$, a maximal of $39.1^{\circ} \mathrm{C}$ and a minimum temperature of $10.8^{\circ} \mathrm{C}$, with 656.1 $\mathrm{mm}$ of average annual rainfall, most of which falls during the rainfall season (June - October) and some precipitation (20 - $60 \mathrm{~mm}$ ) occurs in the northwind season from November to February (Orellana, 1999)

Drought tolerance. Plant size was defined as maximal leaf length (Schmidt y Zotz, 2002). Maximal leaf length for small plants (S1) was $9.6 \pm 0.4 \mathrm{~cm}$ (mean \pm standard deviation) and tank volume was $13.8 \pm 0.5 \mathrm{ml}$. Maximal leaf length for larger plants (S2) was $35.6 \pm 1.2 \mathrm{~cm}$ and tank volume was $75 \pm 3.1 \mathrm{ml}$. Ten plants per size and site were acclimated for 4 weeks to $22.5 \mathrm{~mol} \mathrm{~m}^{-2} \mathrm{~d}^{-1}$ PPFD, $33.0 \pm 0.5 / 23.1 \pm$ $0.7{ }^{\circ} \mathrm{C}$ diurnal/nocturnal air temperature and well-watered conditions. PPFD and temperature were similar to those in the microhabitats where Tillandsia dasyliriifolia grows (R.J. Castillo unpublished data). The impact of drought was measured using the visual wilting stages method developed by Engelbrecht and Kursar (2003), based on leaf angle, leaf rolling and we included a necrosis percent value.

Leaf measurements. Thickness was measured in the middle part of the leaf of 30 well hydrates plants of Tillandsia dasyliriifolia using a digital caliper. To determinate the parenchyma percentage in completely expanded leaves were transversally sectioned in the middle of the blade using a razor blade. Temporary slides were made for study using light microscopy. Digital photographs were taken with an objective lens of $4 \times$, photographs were analyzed with ImageJ $1.48 \mathrm{c}$ software (Wayne Rasband, National Institutes of Health, USA).

Extreme temperature tolerance. For this experiment, San Benito and Ria Lagartos plants were acclimated to day/night ambient temperatures of $30 / 20^{\circ} \mathrm{C}$ (mean temperature of the rainy season in the Yucatan Peninsula, (Cervera et al., 2006), $50 \%$ of total daily PPFD and tanks were refilled every second day. For each site, we selected seven individuals for each plant size, S1 and S2. Tolerance was determined using the vacuolar uptake of the vital stain neutral red (3-amino-7dimethylamino-2- methylphenazine hydrochloride, Sigma, Didden-Zopfy and Nobel, 1982). Stain uptake only occurs in living cells (Nobel and De la Barrera, 2003).

Five leaves per treatment were cut; we choose the middle leaves of the rosette, tissues samples were wrapped in moistened tissue paper and aluminum foil to avoid desiccation. Samples were exposed to air temperatures from $5^{\circ} \mathrm{C}$ to $65^{\circ} \mathrm{C}$, with $5^{\circ} \mathrm{C}$ increases, for one hour. Temperature was monitored 
using a copper-constantan thermocouples in contact with the leaf sample. Low temperatures were obtained in a freezer, intermediate temperatures were obtained using a growth chamber and high temperatures were obtained with a heat dry incubator (EI40-AID, NOVATECH, Guadalajara, Mexico).

After the exposure to temperature treatments, samples were sliced with a razor blade, and were placed in $0.01 \%$ w/v neutral red in distillate water during ten minutes and washed for ten minutes in distillate water. Then 130 intact chlorenchyma cells were examined at $100 \times$ using a $\mathrm{BH}-2$ phase-contrast light microscope (Axioplan - Zeiss, Germany) to check for stained cells. The Lethal low-temperature $\left(\mathrm{LLT}_{50}\right)$ and lethal high temperature $\left(\mathrm{LHT}_{50}\right)$ were defined as the lower and higher temperatures, respectively, which halved stain uptake from the maximum occurring for the control at $25^{\circ} \mathrm{C}$ (Didden-Zopfy and Nobel, 1982).

Statistical analysis. A two-way analysis of variance (ANOVA), followed by Tukey's test were used to test differences between sites and sizes. Arcsine square root transformation was used to achieve normality (Sokal and Rohlf, 1969). Drought tolerance was measured as the number of days needed for the $50 \%$ of the leaves to pass to the next phase of wilting. Statistical analyses were performed using STATGRAPHICS Centurion XV, version 15.2.06 (StatPoint, Inc.).

\section{Results}

Drought tolerance. After 61 days of drought, $100 \%$ of the leaves of the smaller plants (S1) from Ria Lagartos were dead (Fig. 1a). At the same time, for San Benito individuals $95 \%$ of the leaves were dead (Fig. 1b). The first responses to drought were observed at the ninth day of drought for plants from Ria Lagartos and for plants from San Benito, one day later. Both spent most time in the normal stage without showing any wilting responses and they rapidly progressed through the other wilting stages. For plants of Ria Lagartos and San Benito $50 \%$ of the leaves reached the dead stage after 43 and 46 days, respectively.

For S2 plants, about $50 \%$ of the leaves were dead after 65 and 67 days of drought for Ria Lagartos and San Benito respectively. In general plants passed more gradually from the normal stage to the slightly wilted stage, but San Benito plants passed more time in the wilted stage than Ria Lagartos plants, after the wilted stage they process was faster (Fig. 1c, d). We found differences between plant sizes but not between sites $(P<0.05$, Fig. 1$)$. However, there was a $2.5^{\circ} \mathrm{C}$ difference in tolerance between plant sizes $(P<0.05)$.

Leaf measurements. Tillandsia dasyliriifolia leaves had an average thickness of $0.95 \pm 0.031 \mathrm{~mm}$. The leaf blade is equifacial and it consists of epidermis, sclerenchyma, vascular bundles, chlorenchyma and hydrenchyma. As we expected the hydrenchyma tissue occupied almost of the $70 \%$ of the area of the T. dasyliriifolia blade and a $31 \%$ were chorenchyma $(P<0.05)$.
Extreme temperature tolerance. Extreme low temperature was similar for smaller plants (S1), lethal low temperatures $\left(\mathrm{LLT}_{50}\right)$ were $11.95 \pm 0.064{ }^{\circ} \mathrm{C}$ for San Benito and $11.92 \pm$ $0.047{ }^{\circ} \mathrm{C}$ for Ria Lagartos. A strong reduction on the uptake of the stain was observed when tissues were exposed at $15^{\circ} \mathrm{C}$ and a decrement of the $93 \%$ on the uptake occurred at $5{ }^{\circ} \mathrm{C}$. Lethal high temperatures $\left(\mathrm{LHT}_{50}\right)$ for $\mathrm{S} 1$ plants were similar for both sites, $40.85 \pm 0.095^{\circ} \mathrm{C}(P>0.05)$.

For larger plants (S2) the $\mathrm{LLT}_{50}$ was $9.125 \pm 0.047^{\circ} \mathrm{C}$ for San Benito and $9.15 \pm 0.288^{\circ} \mathrm{C}$ for Ria Lagartos. In contrast the $\mathrm{LHT}_{50}$ showed for $\mathrm{S} 2$ plants was higher in comparison with S1 plants, $43.2 \pm 0.081{ }^{\circ} \mathrm{C}$ and $43.1 \pm 0.057{ }^{\circ} \mathrm{C}$, San Benito and Ria Lagartos respectively. The $\mathrm{LLT}_{50}$ and LHT were similar between sites.

\section{Discussion}

Differences in drought tolerance have been found in different life stages in some bromeliads (Benzing and Dahle, 1971). The primary reason of this could be the anatomical advantages related to plant size, such as larger tank. For example for Catopsis sessiliflora (Ruiz \& Pav.) Mez, an epiphytic bromeliad, exhibit a strong correlation between tank water capacity plant sizes. Larger individuals can withhold more water than smaller ones (Zotz and Laube, 2005). Also, the time in which the tank is empties is related to plant size. Smaller individuals of Tillandsia fasciculata Sw. and Guzmania monostachya (L.) Rusby ex Mez passed more time without water in the tank than larger individuals (Zotz and Thomas, 1999).

The differences related to the plant size were observed in early ontogeny. For example, six-month old germinated seedlings of Tillandsia flexuosa Sw. exhibited more tolerance than recently germinated seedlings (Bader et al., 2009). In some bromeliads was observed an inverse relation of rate of water loss with plant size. Smaller plants of Guzmania monostachya (L.) Rusby ex Mez loss more water by transpiration than larger plants. However to Tillandsia fasciculata Sw. water loss if not affected by the plant size (Zotz and Andrade, 1998).

Other advantage against drought and desiccation is the amount of hydrenchyma tissues (Barcikowski and Nobel, 1984). For example, after 50 days of drought the metabolizing region of Tillandsia ionantha Planch. leaf not shows a strong desiccation, allowing a positive assimilation of $\mathrm{CO}_{2}$; consequence of water movement from the hydrenchyma to the chlorenchyma (Nowak and Martin, 1997). Moreover, the presence of hydrenchyma in Tillandsia usneoides allowed an increase of $700 \%$ in tissue water content after a rain and a reduction of $300 \%$ after a severe drought (Penfound and Deiler, 1947).

Furthermore, a dense layer of trichomes have the inverse effect in water loss; they help regulate leaf temperature and transpiration through increased light reflectance (Ehleringer, 

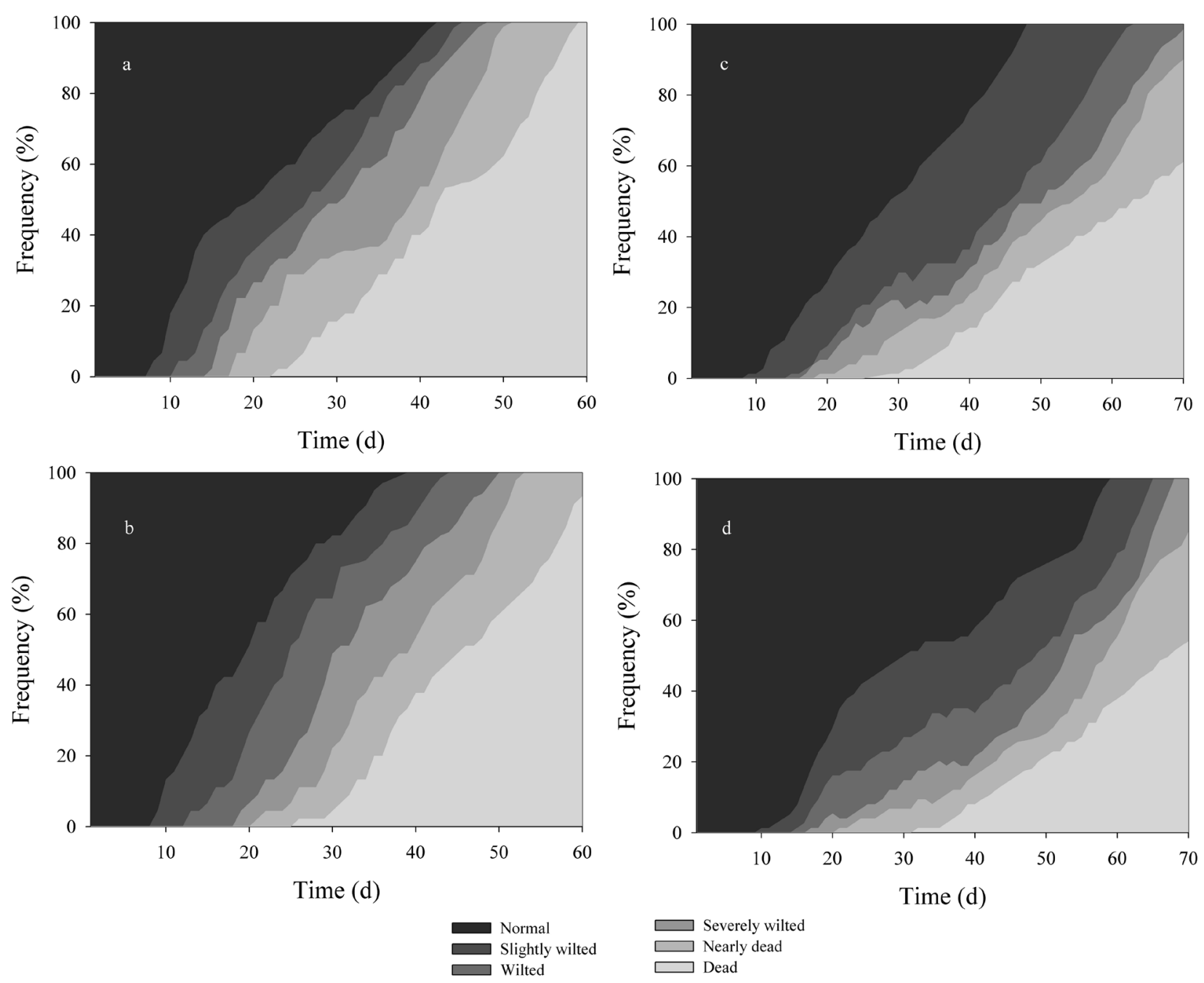

Figure 1. Time course of wilting of Tillandsia dasyliriifolia, on left small individual from Ria Lagartos a), form San Benito b). On the right larger plants form Ria Lagartos c) and from d) San Benito. Growing in controlled conditions, $22.57 \mathrm{~mol} \mathrm{~m}^{-2} \mathrm{~d}^{-1} \mathrm{PPFD}, 33.02 \pm 0.49 / 23.12$ $\pm 0.66{ }^{\circ} \mathrm{C}$ diurnal/nocturnal temperature $(n=10$ per treatment). Different shading refers to different wilting stages.

1984; Ohrui et al., 2007). Low stomatal density and crassulacean acid metabolism (CAM, Martin, 1994; Ricalde et al., 2010) are other adaptations of Tillandsia dasyliriifolia to arid environments to avoid desiccation.

As a general rule, low temperatures are used to explain species abundance in colder regions mainly because of damage by frost (Zotz, 2005). Low temperature causes change in carbohydrate metabolism, hormonal regulation and inhibit or decreases plant growth (Nievola et al., 2005; Guy et al., 2008; Hua, 2009; Mollo et al., 2011). Only a few bromeliads can tolerate low temperatures. For example, some Puyas and Tillandsia usneoides can survive and grow in cold regions such as northern USA (Benzing, 1980; 2000). In this way is not surprising that Tillandsia dasyliriifolia individuals were less tolerant to low temperatures than high temperatures. Low lethal temperature $\left(\mathrm{LLT}_{50}\right)$ for adult individuals was similar to the $\mathrm{LLT}_{50}$ of Mammillaria gaumeri (Britton \& Rose) Orcutt seedlings, a rare cactus endemic to northern Yucatan; acclimate at air temperature of $30 / 20{ }^{\circ} \mathrm{C}$ (Cervera et al. 2006).

High temperature in epiphytes alters cellular and metabolic processes damages cell membranes, inhibiting of chlorophyll synthesis and affects chlorophyll degradation, reduce biomass and flowering furthermore some of them exhibit low acclimation (Vaz et al., 2004; Pisani et al., 2007). Like Vriesea 'cathy' an epiphytic bromeliad shows a decrease in growth, when the temperature increases $5{ }^{\circ} \mathrm{C}$ (Pelligrini, 2012).

Compared with other succulent plants, such as agaves and cacti that growth in North American deserts, which can tolerate temperatures below $0{ }^{\circ} \mathrm{C}$ and above $65^{\circ} \mathrm{C}$, Tillandsia dasyliriifolia exhibits a moderate tolerance temperature (Nobel and De la Barrera, 2003; Nobel and Zutta, 2007; Drennan, 2009). Even the $\mathrm{LHT}_{50}$ of Hylocereus undatus (Haw.) Britton \& Rose, a co-ocurring hemiepiphytic cactus is higher, similar Mammillaria gaumeri which exhibits a 


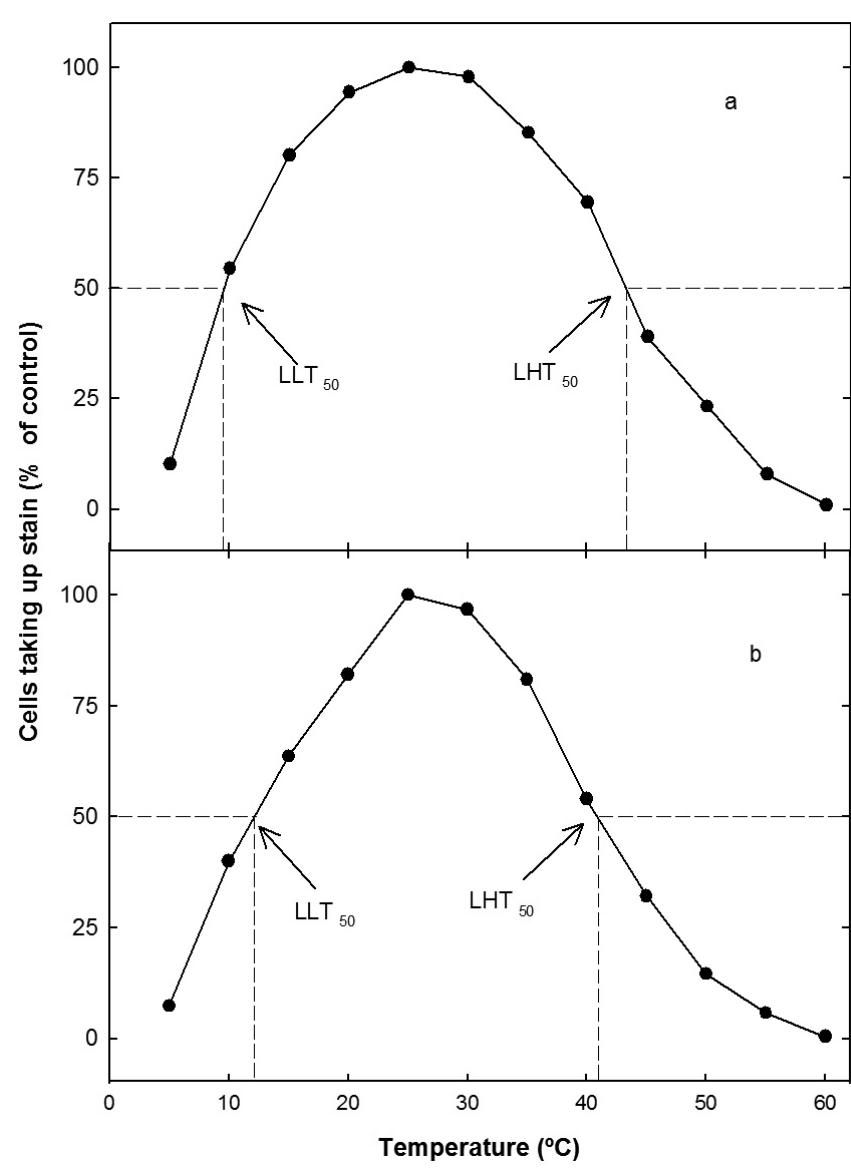

Figure 2. Effect of high and low temperature treatments on cell viability of Tillandsia dasyliriifolia adult larger (a) and smaller (b). Acclimated in controlled conditions to a diurnal/nocturnal temperature of $30 / 20{ }^{\circ} \mathrm{C}$ and $50 \%$ of total daily PPFD. Data are expressed relative to the control at $25{ }^{\circ} \mathrm{C}$ (for which $100 \%$ of the chlorenchyma cells took up stain).

$\mathrm{LHT}_{50}$ above $5^{\circ} \mathrm{C}$ (Nobel and De la Barrera, 2002; Cervera et al., 2006).

Our results suggest that Tillandsia dasyliriifolia exhibited a moderate tolerance to drought and extreme temperatures. We confirmed the effect of plant size on drought tolerance and demonstrated that extreme temperature tolerance is also affected. Although differences in precipitation and microclimate of populations of origin were not significant, it is recommended that more studies with populations with more marked differences. Future research must focus on the responses of acclimation with respect to rising air temperatures and changes in the precipitation regiments accompanying global climate change.

\section{Acknowledgments}

This study was financially supported by the Consejo Nacional de Ciencia y Tecnología (CONACYT- CB2009133180).

\section{Literature Cited}

Adams III W.W. and Martin C.E. 1986a. Physiological consequences of change in life form in the Mexican epiphyte Tillandsia deppeana (Bromeliaceae). Oecologia 70:298-304.

Adams III W.W. and Martin C.E. 1986b. Morphological changes accompanying the transition from juvenile (atmospheric) to adult (tank) forms in the Mexican epiphyte Tillandsia deppeana (Bromeliaceae). American Journal of Botany 73:1207-1214.

Adams S.R., Pearson S. and Hadley P. 1997. An analysis of the effects of temperature and light integral on the vegetative growth of pansy cv. Universal Violet (Viola $x$ wittrockiana Gams). Annals of Botany 79:219-225.

Bader M.Y., Menke G. and Zotz G. 2009. Pronounced drought tolerance characterizes the early life stages of the epiphytic bromeliad Tillandsia flexuosa. Functional Ecology 23:472-479.

Barcikowski W. and Nobel P.S. 1984. Water relations of cacti during desiccation: distribution of water in tissues. Botanical $\mathrm{Ga}$ zette 145:110-115.

Benzing D.H. 1978. Germination and early establishment of Tillandsia circinnata Schlecht. (Bromeliaceae) on some of its hosts and other supports in Southern Florida. Selbyana 5:95-106.

Benzing D.H. 1980. The Biology of the Bromeliads. Mad River Press, Eureka.

Benzing D.H. and Dahle C.E. 1971. The vegetative morphology, habitat preference and water balance mechanisms of the bromeliad Tillandsia ionantha Planch. The American Midland Naturalist 85:11-21.

Benzing D.H. 2000. Bromeliaceae: profile of an adaptive radiation. Cambridge University Press, Cambridge.

Carter P.J, Wilkins M.B., Nimmo H.G. and Fewson C.A 1995. Effects of temperature on the activity of phosphenolpyruvate carboxylase and on the control of $\mathrm{CO}_{2}$ fixation in Bryophyllym fedtschenkoi. Planta 196:375-380.

Cervera J.C., Andrade J.L., Simá J.L. and Graham E.A. 2006. Microhabitats, germination, and establishment for Mammillaria gaumeri (Cactaceae), a rare species from Yucatan. International Journal of Plant Sciences 167:311-319.

Penfound Wm. T. y Deiler F.G. 1947. On the ecology of Spanish moss. Ecology 28:455-458.

Didden-Zopfy, B. and Nobel P.S. 1982. High-temperature tolerance and heat acclimation of Opuntia bigelovii. Oceologia 52:176-180.

Drennan P.M. 2009. Temperature influences on plant species of arid and semi-arid regions with emphasis on CAM succulents. In: De la Barrera E. and Smith W.K. Eds. Perspectives in Biophysical Plant Ecophysiology. A Tribute to Park S. Nobel, pp 57-94, Universidad Nacional Autónoma de México, México D.F.

Ehleringer J. 1984. Ecology and ecophysiology of leaf pubescence in North American desert plants. In: Rodriguez E, Healey PL and Mehta I. Eds. Biology and chemistry of plant trichomes, pp.113-132, Plenum, New York.

Ehleringer J.R. and R.K. Monson. 1993. Evolutionary and ecological aspects of photosynthetic pathway variation. Annual Review of Ecology and Systematics 24:411-439.

Engelbrecht B.M.J. and Kursar T.A. 2003. Comparative droughtresistance of seedlings of 28 species of co-ocurring tropical woody plants. Oecologia 136:383-393.

Garth R.E. 1964. The ecology of spanish moss Tillandsia usneoides: its growth and distribution. Ecology 45:470-481. 
Gibson A. and Nobel P.S. 1986. The cactus primer. Harvard University Press, Cambridge, Massachusetts.

Guy Ch., Kaplan F., Kopka J., Selbig J. and Hincha D.K. 2008. Metabolomics of temperature stress. Physiologia Plantarum 132:220-235.

Hua J. 2009. From freezing to scorching, transcriptional responses to temperature variations in plants. Current Opinion in Plant Biology 12:568-573.

Israel A.A. and Nobel P.S. 1995. Growth temperature versus $\mathrm{CO}_{2}$ uptake, Rubisco and PEPCase activities, and enzyme hightemperature sensitivites for CAM plant. Plant Physiology and Biochemestry 33:345-351.

Lambers H., Chapin III F.S. and Pons T.L. 2008. Plant Physiological Ecology. Springer-Verlag, New York.

Lüttge U. 2004. Ecophysiology of Crassulacean Acid Metabolism (CAM). Annals of Botany 93:629-652.

Martin C.E. 1994. Physiological Ecology of the Bromeliaceae. The Botanical Review 60:1-82.

Mollo L., Martins M.C.M., Oliveira V.F., Nievola C.C. and Figueiredo-Ribeiro R. de C.L. 2011. Effects of low temperature on growth and non-structural carbohydrates of the imperial bromeliad Alcantarea imperialis cultured in vitro. Plant Cell Tissue and Organ Culture 107:141-149.

Nievola C.C., Kraus J.E., Freschi L., Souza B.M. and Mercier H. 2005. Temperature determines the occurrence of CAM or C3 photosynthesis in pineapple plantlets grown in vitro. In Vitro Cellular \& Developmental Biology-Plant 41:832-837.

Nobel P.S. 1988. Environmental Biology of Agaves and Cacti. Cambridge University Press, Cambridge.

Nobel P S. and De la Barrera E. 2002. High temperatures and net $\mathrm{CO}_{2}$ uptake, growth, and stem damage for the hemiepiphytic cactus Hylocereus undatus. Biotropica 34:225-231.

Nobel P S. and De la Barrera E. 2003. Tolerances and acclimation to low and high temperatures for cladodes, fruits and roots of a widely cultivated cactus, Opuntia ficus-indica. New Phytologist 157:271-279.

Nobel P.S. and Zutta B.R. 2007. Rock associations, root depth, and temperature tolerances for the "rock live-forever," Dudleya saxosa, at three elevations in the north-western Sonoran Desrt. Journal of Arid Environments 69:15-28.

Nowak E.J. and Martin C.E. 1997. Physiological and anatomical responces to water deficits in the CAM epiphyte Tillandsia ionantha (Bromeliaceae). International Journal of Plant Sciences 158:818-826.

Ohrui T., Nobira H., Sakata Y., Taji T., Yamamoto C., Nishida K., Yamakawa T., Sasuga Y., Yaguchi Y., Takenaga H., and Tanaka S. 2007. Foliar trichome- and aquaporin-aided water uptake in a drought-resistant epiphyte Tillandsia ionantha Planchon. Planta 227:47-56.

Orellana R. 1999. Evaluación Climática. In: P. Chico-Ponce de León Eds. Atlas de los Procesos Territoriales de Yucatán, pp. 163-182, Universidad Autónoma de Yucatán, Mérida.

Orellana R., Espadas C., Conde C. y Gay C. 2009. Atlas. Escenarios de Cambio Climático en la Península de Yucatán. Centro de Investigación Científica de Yucatán, A.C. Mérida.

Palta J.P., Whitaker B. D. and Weiss L.S. 1993. Plasma membrane lipids associated with genetic variability in freezing tolerance and cold acclimation of Solanum species. Plant Physiology 103:793-803.

Pastenes C. and Horton P. 1996. Effect of high temperature on photosynthesis in beans (II. $\mathrm{CO}_{2}$ assimilation and metabolite contents). Plant Physiology 11:1253-1260.

Pelligrini, A. 2012. Temperature and Nutrient Change and Their Evolutionary Consequences. Colgate Academic Review 6: article 3.

Pisani T., Paoli L., Gaggi C., Pirintsos S.A. and Loppi S. 2007. Effects of high temperature on epiphytic lichens: Issues for consideration in a changing climate scenario. Plant Biosystems 141:164-169.

Ricalde M.F., Andrade J.L., Durán R., Dupuy J.M., Simá J.L., UsSantamaría R. and Santiago L.S. 2010. Environmental regulation of carbon isotope composition and crassulacean acid metabolism in three plant communities along a water availability gradient. Oecologia 164:871-880.

Sanford W.W. 1969. The distribution of epiphytic orchids in Nigeria in relation to each other and to geographic location and climate, type of vegetation and tree species. Biological Journal of the Linnean Society 1:247-285.

Schmidt G. and Zotz G. 2001. Ecophysiological consequences of differences in plant size: in situ carbon gain and water relations of the epiphytic bromeliad, Vriesea sanguinolenta. Plant, Cell \& Environment 24:101-111.

Schmidt G. and Zotz G. 2002. Inherently slow growth in two Caribbean epiphytic species: A demographic approach. Journal of Vegetation Science 13:527-534.

Schmidt G., Stuntz S. and Zotz G. 2001. Plant size: an ignored parameter in epiphyte ecophysiology? Plant Ecology 153:65-72.

Smith S.D., Monson R.K. and Anderson J.E. 1997. Physiological Ecology of North American Desert Plants. Springer-Verlag, Berlin Heidelberg.

Sokal R.R. and Rohlf J.H. 1969. Biometry: The Principles and Practice of Statistics in Biological Research. W. H. Freeman, San Francisco.

Vaz A.P.A., Figueiredo-Ribeiro R.C.L. and Kerbauy G.B. 2004. Photoperiod and temperature effects on in vitro growth and flowering of P. pusilla, an epiphytic orchid. Plant Physiology and Biochemistry 42:411?415.

Winter K. and Smith J.A.C. 1996. Crassuacean acid metabolism. Biochemistry, Ecophysiology and Evolution, Ecological Studies Vol. 14. Springer-Verlag, Berlin, Heidelberg.

Zotz G 1997. Photosynthetic capacity increases with plant size. Botanica Acta 110: 306-308.

Zotz G. 2005. Vascular epiphytes in the temperate zones-a review. Plant Ecology 176:173-183.

Zotz G. and Andrade J.L. 1998. Water relations of two co-occurring epiphytic bromeliads. Journal of Plant Physiology 152:545-549.

Zotz G. and Laube S. 2005. Tank function in the epiphytic bromeliad Catopsis sessiliflora. Ecotropica 11:63-68.

Zotz G. and Thomas V. 1999. How much water is in the Tank? Model calculations for two epiphytic bromeliads. Annals of botany 83:183-192. 